\title{
Unsuccessful weaning from mechanical ventilation in children and ways to avoid it
}

\begin{abstract}
The aim of the work: to determine causes of unsuccessful weaning depending on subglottic edema markers, level of sedation and sedation-agitation, changes in neurological status and bulbar disorders in children with different types of respiratory failure.

Materials and Methods. We conducted a prospective cohort single-center study at the Department of Anesthesiology and Intensive Care at Lviv Regional Children's Clinical Hospital "OHMATDYT". We included 89 patients aged 1 month - 18 years with acute respiratory failure who was mechanically ventilated for more than 3 days. They were randomly divided into 2 groups. Group I included patients who received lung-protective ventilation strategy and assessment central nervous system function and the percentage of leakage of the gas mixture near the endotracheal tube; group II - patients who received diaphragm-protective in addition to lung-protective ventilation strategy and took into account the results of central nervous system assessment and respiratory gas mixture leakage near endotracheal tube during weaning from mechanical ventilation. The primary endpoint was the frequency of reintubations, the secondary endpoint was the frequency of complications (tracheostomy). 82 patients were included in the data analysis. Patients were divided into age subgroups: subgroup 1 - children 1 month -1 year; subgroup - children 1-3 years; subgroup 3 - children 3-6 years; subgroup 4 - children 6-13 years; subgroup 5 - children 13-18 years.

Results and Discussion. The frequency of reintubations in patients of the age subgroup 1 was reduced in group II to $5.3 \%$ compared with $22.7 \%$ in group I ( $\mathrm{p}=0.02$ ), which was accompanied by a higher frequency of elective tracheostomy (before the first attempt of weaning from mechanical ventilation) which was $11 \%$ in comparison with $0 \%, \mathrm{p}=0.001$ ). The frequency of reintubations in the age subgroup 2 was reduced to $5.9 \%$ in group II vs $20 \%$ in group I ( $=0.04$ ), and elective tracheostomy was performed in $18 \%$ patients in group II vs $5 \%$ patients in group I ( $\mathrm{p}=0.05)$.

There were no significant differences in the frequency of reintubations among patients in the age subgroup 3 (14.2\% in group I vs $11.1 \%$ in group II, $\mathrm{p}=0.31$ ); in the age subgroup 4 ( $13 \%$ vs $17 \%, \mathrm{p}=0.19)$; the age subgroup 5 ( $6 \%$ vs $7 \%$, p $=0.72$ ).
\end{abstract}

Key words: mechanical ventilation; children.

Problem definition and analysis of recent research and publications. Children might be often admitted to pediatric intensive care units (PICU) due to acute respiratory failure (ARF). 30-64 \% of such patients need to be mechanically ventilated (1), and later after regression of ARF symptoms they have to be weaned from mechanical ventilation (MV). However, this process is not always easy, and frequency of unsuccessful weaning is from 6.2 to $36 \%$ in adult patients and more than $50 \%$ in children [2]. Early weaning and extubation might lead to sudden deterioration of cardiovascular and respiratory systems, on the other hand, prolonged MV with high level of support in 29$80 \%$ of patients is associated with atrophy and dysfunction of diaphragm [3]. Typical causes of unsuccessful weaning from MV are cardiovascular disorders [4], malnutrition [5], electrolyte disorders [6], neurological disorders with loss of cough and swallowing reflexes [7], diaphragm dysfunction [10] and intensive care unit-acquired limb muscle weakness [1].

The aim of the work: to determine the causes of unsuccessful weaning depending on subglottic edema markers, level of sedation and sedation-agitation, changes in neurological status and bulbar disorders in children with different types of respiratory failure.
Materials and Methods. We conducted a prospective cohort single-center study at the Department of Anesthesiology and Intensive Care at Lviv Regional Children's Clinical Hospital "OHMATDYT". Inclusion criteria were: ARF, age 1 month - 18 years; invasive MV. Exclusion criteria included: refusal of the patient's legal representatives to participate in the study both before and at any of its stages; chronic respiratory failure; congenital heart disease; terminal illness.

We included 89 patients aged 1 month - 18 years with acute respiratory failure who were mechanically ventilated for more than 3 days (Fig. 1). 82 patients were included in the data analysis. They were randomly divided into 2 groups. Group I included patients who received lung-protective ventilation strategy and assessment central nervous system function and the percentage of leakage of the gas mixture near the endotracheal tube; group II - patients who received diaphragm-protective in addition to lung-protective ventilation strategy and took into account the results of central nervous system assessment and respiratory gas mixture leakage near endotracheal tube during weaning from mechanical ventilation. 


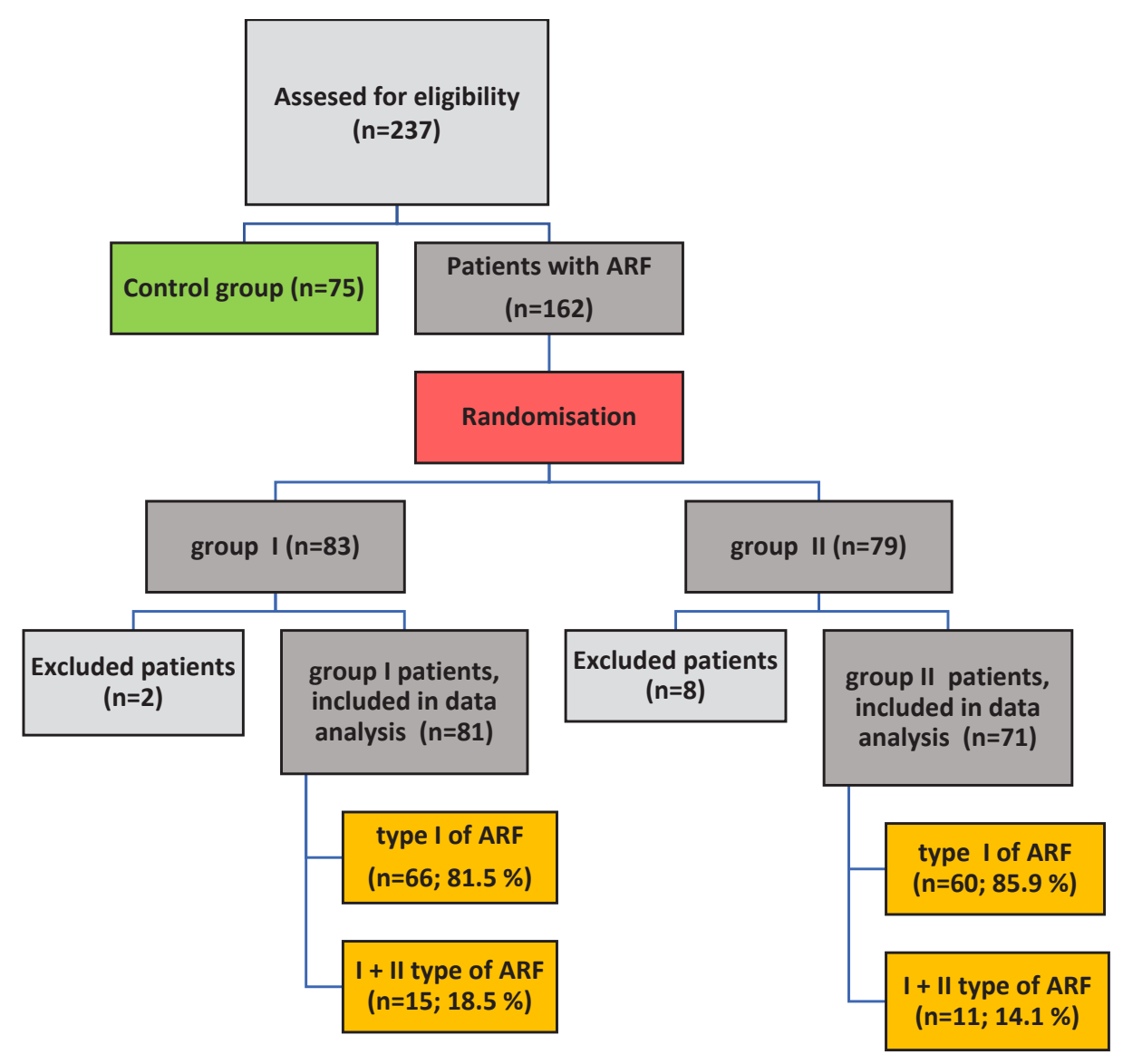

Figure 1. Flow diagram of the study.

Central nervous system function was assessed as follows: we search for history of bulbar disorders prior admission to the PICU, check level of consciousness according to Glasgow Coma Scale and FOUR scale (which in addition to Glasgow Come Scale contains evaluation of brain stem function and respiration pattern), assess presence of cough and swallowing reflexes, use Ramsay and Richmond scales for establishing sedation and sedation-agitation level I. In patients of group I the cut-off point for checking swallowing and cough reflexes was result less than 9 points according GCS and take it into account during weaning from MV.

Swallowing reflex was checked with stimulation on root of tongue, in case of its presence, the act of swallowing should be carried out involuntarily. Presence of cough reflex was checked during airway suctioning with soft elastic catheter which contact with posterior surface of epiglottis, anterior surface of larynx between the laryngeal cartilages, vocal cords and subglottic space, tracheal bifurcation and segmental bronchi bifurcation.

According to acid-base balance results and etiology of disease, patients of both groups were divided into those who had type I of ARF (hypoxemic) and those, who had combination of types I and II of ARF (hypoxemic-hypercapnic). To assess age-dependent data patients were divided into age subgroups: subgroup 1 - children 1 month - 1 year old; subgroup 2 children $1-3$ years old; subgroup 3 - children $3-6$ years old; subgroup 4 - children 6 - 13 years old; subgroup 5 - children $13-18$ years old.

Stages of the study: 1st day (d1), 3rd day (d3), 5th day (d5), 7th day (d7), 9th day (d9), 14th day (d14), 28th day (d28).

Respiratory therapy was performed by ventilators "Hamilton C1", "Hamilton C3", "VELA" in pressure to control modes with taking into account "Recommendations for mechanical ventilation of critically ill children from the Pediatric Mechanical Ventilation Consensus Conference (PEMVECC), 2016", and lungprotective strategy, which had the aim to limit tidal volume less than $6 \mathrm{ml} / \mathrm{kg}$ body weight, Pplato (plateau pressure) less than $28 \mathrm{~cm} \mathrm{H2O}$, delta pressure less than $10 \mathrm{~cm} \mathrm{H20}$, and chose such Tin (inspiratory time), that at least two RCexp (exhalation constants) will remain on exhalations. The aim was to maintain $88-95 \%$ of blood saturation, $\mathrm{PaO} 2$ over $55-80 \mathrm{~mm} \mathrm{Hg}, \mathrm{PaCO} 2$ below 55-60 mm Hg. Diaphragm-protective strategy of MV means to maintain spontaneous diaphragmatic activity in patients (with no muscle relaxants administra- 
tion in case of sufficient oxygenation level and patient's good synchronization with the ventilator), the fraction of diaphragm thickening on ultrasonography over $15 \%$ with amplitude of movements 8-10 mm.

In group II of patients the criteria for readiness for weaning from MV were: level of consciousness according GCS over 11 points, according FOUR scale - over 12 points, level of sedation-agitation according Richmond scale over -1 and less than 1 point, presence of cough and swallowing reflexes, leakage of gas mixture near endotracheal tube more than $15 \%$ of the total minute volume ventilation. We have monitored cuff pressure (on endotracheal tube) with time frame $6-8 \mathrm{~h}$, and aim was to maintain cuff pressure $20-30 \mathrm{~mm} \mathrm{Hg}$.

The primary endpoint was the frequency of reintubations, the secondary endpoint was the frequency of complications (tracheostomy).

Statistical analysis of the study results was performed using MS Excel 2017 with the calculation median [IQR - interquartile range], mean value taking into account the standard deviation $(\mathrm{M} \pm \sigma)$, the level of significance p.

Results and Discussion. We made the analysis of etiology of diseases which led to ARF and found out that pneumonia was confirmed in 63 patients (77.8\%) in group I and in 61 patients (85.9\%) in group II, $\mathrm{p}=0.03$; acute respiratory distress syndrome (ARDS) was confirmed only in 3 patients in group I (3.7 \%), $\mathrm{p}=0.89$; bronchopulmonary dysplasia in combination with pneumonia was detected in 5 patients $(6.2 \%)$ in group I and in 4 patients (5.6 \%) in group II, $\mathrm{p}=0.02$; acute obstructive bronchitis/bronchiolitis/bronchial asthma in combination with pneumonia were confirmed in 10 patients (12.3 \%) in group I and in 6 patients $(8.5 \%)$ in group II, $\mathrm{p}=0.08$.

The frequency of reintubations in patients of the age subgroup 1 was reduced in group II to $5.3 \%$ compared with $22.7 \%$ in group I ( $\mathrm{p}=0.02)$, which was accompanied by a higher frequency of elective tracheostomy (before the first attempt of weaning from mechanical ventilation) which was $11 \%$ in comparison with $0 \%, \mathrm{p}=0.001$ ). The frequency of reintubations in the age subgroup 2 was reduced to $5.9 \%$ in group II vs $20 \%$ in group I $(p=0.04)$, and elective tracheostomy was performed in $18 \%$ patients in group II vs $5 \%$ patients in group I $(\mathrm{p}=0.05)$.

Comorbidities, surgery procedures and interventions, pediatric risk of mortality and organ dysfunction levels are given in Table.1.

According to arterial blood acid-base balance results, it was found that there were $58 \%$ with hypo-

Table 1. Characteristics of patients

\begin{tabular}{|c|c|c|c|}
\hline Parameters & Group I (n=81) & Group II (n=71) & $\mathrm{P}^{\mathrm{a}}$ \\
\hline \multicolumn{4}{|c|}{ Comorbidities, number, (\%) } \\
\hline Septic shock & $24(29.6 \%)$ & $21(29.6 \%)$ & 0.92 \\
\hline Catechol-resistant septic shock & 10 (12.3 \%) & $8(11.3 \%)$ & 0.74 \\
\hline Acute cardiovascular failure & $2(2.5 \%)$ & $1(1.4 \%)$ & 0.23 \\
\hline Malnutrition & 49 (60.5 \%) & $45(63.4 \%)$ & 0.32 \\
\hline Encephalopathy & $26(32,1 \%)$ & $22(31 \%)$ & 0.11 \\
\hline Neuromuscular disorders & 0 & $1(1.4 \%)$ & 0.09 \\
\hline \multicolumn{4}{|c|}{ Surgery procedures and interventions, number, (\%) } \\
\hline Laparotomy and drainage & 18 (22.2 \%) & $13(18.3 \%)$ & 0.64 \\
\hline Thoracocentesis and chest drain insertion & $12(14.8 \%)$ & $14(19.7 \%)$ & 0.33 \\
\hline Tracheobronchoscopy & $36(44.4 \%)$ & $29(40.8 \%)$ & 0.03 \\
\hline \multicolumn{4}{|c|}{ Pediatric risk of mortality level and organ dysfunction level } \\
\hline PRISM III, points & $18.4 \pm 0.7$ & $16.4 \pm 0.9$ & 0.27 \\
\hline Predicted mortality, \% & $10.1 \pm 2.6$ & $12.6 \pm 3.8$ & 0.12 \\
\hline P-MODS, points & $5.2 \pm 0.3$ & $4.1 \pm 0.4$ & 0.18 \\
\hline
\end{tabular}

Data are expressed as mean \pm SD or number (\%); $a-\chi^{2}$ test to compare two groups. 
xemic (I type) and 42\% with hypoxemic-hypercapnic (I + II type) ARF in 1 age subgroup; $82 \%$ with hypoxemic and $18 \%$ with hypoxemic-hypercapnic ARF in 2nd age subgroup; $100 \%$ had hypoxemic ARF in 3rd age subgroup; $88 \%$ with hypoxemic and $12 \%$ with hypoxemic-hypercapnic ARF in 4th age subgroup; 84 \% with hypoxemic and $16 \%$ with hypoxemic-hypercapnic ARF in 5th age subgroup.

Common for patients with I and I + II types of ARF were tachypnea, high minute volume ventilation and hypoxemia. Unidirectional were also signs of diaphragm dysfunction in all age subgroups. Therefore, the analysis of the studied data was performed in I and II groups with no dividing results according to type of ARF.

It was found that there were no significant differences between group I and II in time when mechanically ventilated patients achieved over $15 \%$ (in comparison with minute volume ventilation) of respirato- ry mixture gas leakage near endotracheal tube: in the 1st age subgroup it was achieved on d9 , in 2nd and 3rd age subgroups - on d7, in the 4th and 5th age subgroups - on d3. However, the frequency of postintubation stridor with need for reintubation and MV had significant differences and in 1st age subgroup where it was $14 \%$ in group I in comparison with $5 \%$ in group II, $\mathrm{p}=0.02$; in 2 nd age subgroup $-15 \%$ and to $0 \%, p=0.001$, in the 3rd, 4th and 5th age subgroups there were no incidences of postintubation stridor.

The current study shows that there were no significant differences between groups at any stage of the study (Table 2, Fig. 2) in level of consciousness according Glasgow Coma Scale and FOUR scale. On the other hand, it was found that along the study, level of consciousness gradually increased and reach subnormal values on $\mathrm{d} 7$ and $\mathrm{d} 9$ stages in both groups. On $\mathrm{d} 1$ in group I, these parameters were 10 [9.25; 10.75] points and 10 [9; 12] points for GCS and FOUR, re-

Table 2. Central nervous function assessment results

\begin{tabular}{|c|c|c|c|c|}
\hline Variable & Study stage & group I $(n=81)$ & group II (n=71) & $\mathrm{P}^{\mathrm{a}}$ \\
\hline \multirow{5}{*}{$\begin{array}{l}\text { Glasgow Coma Scale, } \\
\text { points }\end{array}$} & $\mathrm{d}_{1}$ & 10 [9.25; 10.75] & $10[9 ; 10.5]$ & 0.93 \\
\hline & $\mathrm{d}_{3}$ & $11[9.5 ; 11.25]$ & $11[9 ; 11.25]$ & 0.42 \\
\hline & $\mathrm{d}_{5}$ & $11[9 ; 11.25]$ & $12[10.5 ; 12.5]$ & 0.56 \\
\hline & $\mathrm{d}_{7}$ & 12 [10.25; 12.25] & $12[11 ; 12.5]$ & 0.87 \\
\hline & $\mathrm{d}_{9}$ & $12[11 ; 13]$ & $13[10.5 ; 13.5]$ & 0.43 \\
\hline \multirow[t]{5}{*}{ FOUR scale, points } & $\mathrm{d}_{1}$ & $10[9 ; 12]$ & $10[9 ; 11.5]$ & 0.98 \\
\hline & $\mathrm{d}_{3}$ & $10[9.5 ; 11.5]$ & $11[10 ; 11.75]$ & 0.45 \\
\hline & $\mathrm{d}_{5}$ & 12 [11.25; 12.5] & 12 [11.5; 13] & 0.72 \\
\hline & $\mathrm{d}_{7}$ & $13[11 ; 13.5]$ & 13 [12; 13.75] & 0.59 \\
\hline & $\mathrm{d}_{9}$ & $14[12 ; 15]$ & $14[12.5 ; 15]$ & 0.65 \\
\hline \multirow{5}{*}{$\begin{array}{l}\text { Ramsay sedation scale, } \\
\text { points }\end{array}$} & $\mathrm{d}_{1}$ & $4[4.5 ; 3.75]$ & $4[4.75 ; 3.5]$ & 0.85 \\
\hline & $\mathrm{d}_{3}$ & $3[4 ; 2.5]$ & $4[4.25 ; 3.5]$ & 0.24 \\
\hline & $\mathrm{d}_{5}$ & $3[4 ; 1.75]$ & $2[3.5 ; 1.75]$ & 0.19 \\
\hline & $\mathrm{d}_{7}$ & $2[2.5 ; 1.5]$ & 2 [2.75; 1.5] & 0.57 \\
\hline & $\mathrm{d}_{9}$ & $2[2.5 ; 1.5]$ & $2[2.25 ; 1]$ & 0.35 \\
\hline \multirow{5}{*}{$\begin{array}{l}\text { Richmond sedation- } \\
\text { agitation scale, points }\end{array}$} & $\mathrm{d}_{1}$ & $-2[-3.25 ;-1]$ & $-1[-1.75 ;-0.5]$ & 0.09 \\
\hline & $\mathrm{d}_{3}$ & $-1[-1.5 ;-0.5]$ & $-1[-1.25 ; 0]$ & 0.42 \\
\hline & $\mathrm{d}_{5}$ & $1[-0.5 ; 1.5]$ & $1[0.5 ; 1.25]$ & 0.32 \\
\hline & $\mathrm{d}_{7}$ & $1[0.5 ; 1.5]$ & $0[-0.5 ; 1]$ & 0.39 \\
\hline & $\mathrm{d}_{9}$ & $1[0.5 ; 2]$ & $0[-1 ; 1]$ & 0.12 \\
\hline
\end{tabular}

Data are presented as median (Q25; Q75); a - Kruskal-Wallis test. 


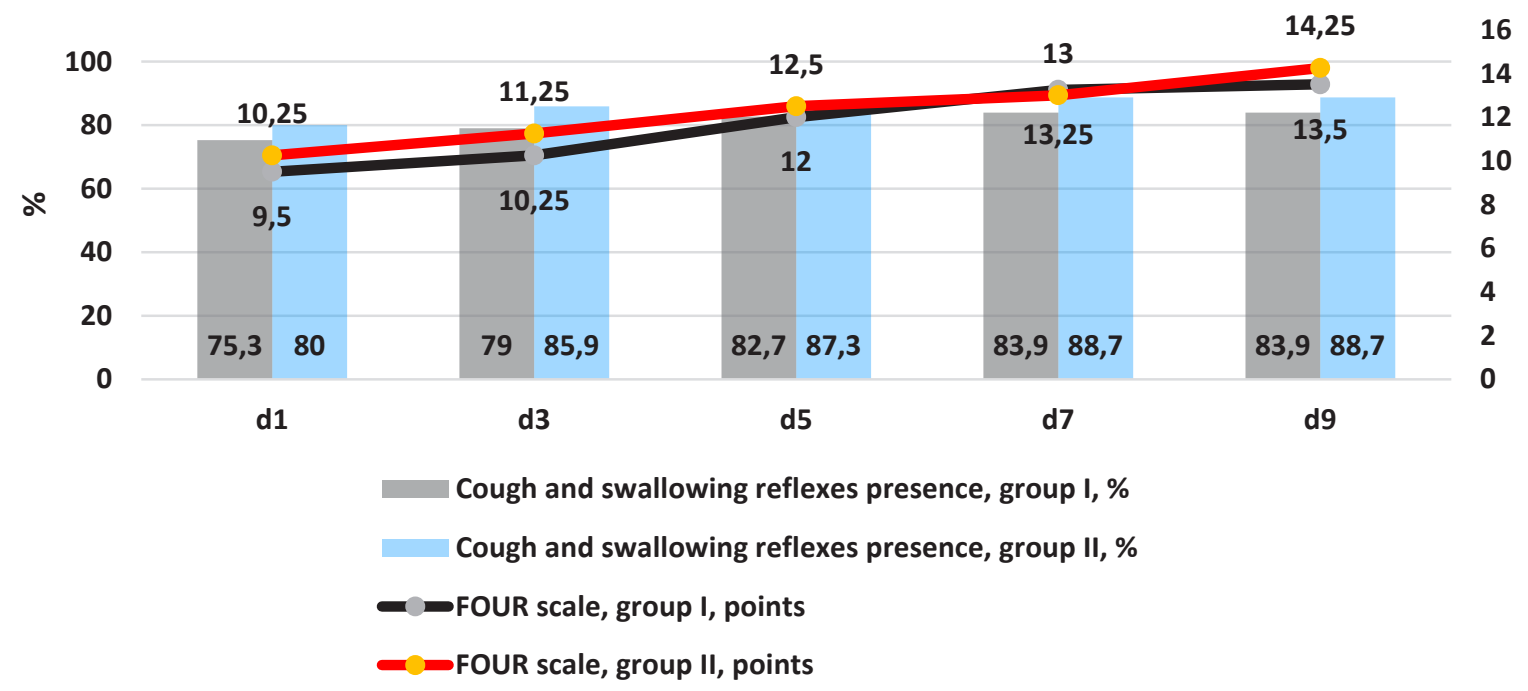

Figure 2. Assessment of central nervous system (FOUR scale) and cough and swallowing reflexes presence.

spectively, and in group II - 10 [9; 10.5] points and $10[9 ; 11.5]$ points $(p=0.93$ and $p=0.98)$. On $d 3$ these indicators were, respectively, in group I 11 [9.5; $11.25]$ points and $10[9.5 ; 11.5]$ points, and in group II $-11[9 ; 11.25]$ points and $11[10 ; 11.75]$ points $(\mathrm{p}=$ 0.42 and $p=0.45$ ). On $d 5$ in group I level of consciousness according GCS was 11 [9; 11.25] points, on $\mathrm{d} 7$ increased up to 12 [10.25; 12.25] points and did not change until $\mathrm{d} 9$, staying on 12 [11; 13] points. In group II level of consciousness according GCS on d5 was $12[10.5 ; 12.5]$ points $(\mathrm{p}=0.56)$, on $\mathrm{d} 7-12$ [11; $12.5]$ points $(\mathrm{p}=0.87)$; on $\mathrm{d} 9$ was increased up to 13 $[10.5 ; 13.5]$ points $(\mathrm{p}=0.43)$.

Whereas according FOUR scale (Table 2, Figure 2) patients of group I were evaluated on d5 in 12 [11.25; 12.5] points, on d7 they had 13 [11; 13.5] points and on $\mathrm{d} 9-14[12 ; 15]$ points. In group II these data were $12[11.5 ; 13]$ points $(\mathrm{p}=0.72)$; increased up to 13 [12; 13.75] points on $\mathrm{d} 7(\mathrm{p}=0.59)$, and up to 14 $[12.5 ; 15]$ points) on $\mathrm{d} 9(\mathrm{p}=0.65)$.

There were no significant intergroup differences in sedation level (Ramsay scale) at all stages of the study (Table 2). This level was gradually decreased from $\mathrm{d} 1$ to $\mathrm{d} 9$. On $\mathrm{d} 1$ in groups I and II these data were $4[4.5 ; 3.75]$ points and $4[4.75 ; 3.5]$ points (p $=0.85)$, on $\mathrm{d} 3-$ decreased in group I to $3[4 ; 2.5]$ points and in group II remained 4 [4.25; 3.5] points $(\mathrm{p}=0.24)$. On d5 in groups I and II, these indicators were, respectively, 3 [4; 1.75] points and 2 [3.5; 1.75] points ( $\mathrm{p}=0.19)$; on $\mathrm{d} 7$ - we also did not find differences and data were $2[2.5 ; 1.5]$ points and 2 [2.75; $1.5]$ points ( $p=0.57)$, respectively. Our finding is the fact that level of sedation 2-3 points according Ramsay scale is safe to begin weaning from $\mathrm{MV}$, andl 2 points - sufficient to complete weaning from MV.
The dynamics of sedation-agitation (Richmond scale) had the following features: on $\mathrm{d} 1$ it was -2 $[-3.25 ;-1]$ points in group I and $-1[-1.75 ;-0.5]$ points in group II $(\mathrm{p}=0.09)$; on $\mathrm{d} 3$ it was $-1[-1.5 ;-0.5]$ points and $-1[-1.25 ; 0]$ points $(\mathrm{p}=0.42)$; on $\mathrm{d} 5 \mathrm{-in-}$ creased in both groups and was $1[-0.5 ; 1.5]$ points and $1[0.5 ; 1.25]$ points $(p=0.32)$. On $d 7$ and $d 9$ in group I it remained on $1[0,5 ; 1.5]$ points and $1[0.5 ; 2]$ points, whereas, in group II it was lower $-0[-0.5 ; 1]$ points and $0[-1 ; 1]$ points $(\mathrm{p}=0.39 ; \mathrm{p}=0.12)$. Thus, the level of sedation-agitation according Richmond scale in patients of group I on $\mathrm{d} 7$ and $\mathrm{d} 9$ were to close to agitation, in comparison with group II.

In the current study presence of cough and swallowing reflexes in both groups of patients are summarized in Table 3, Figure 2. In group I on d1, d3, d5 these data were $75.3 \%$, $79 \%$, $82.7 \%$, become $83.9 \%$, on d7 and did not change more. In group II such data were $80 \%$ on $\mathrm{d} 1$ ( $\mathrm{p}=0.28) ; 85.9 \%$ on d3 ( $\mathrm{p}=0.12), 87.3 \%$ on d5 ( $p=0.23)$; and $88.7 \%$ from d7 ( $=0.41)$.

Our study demonstrated that for patients with different types of ARF in case of bulbar disorders and inability to swallow liquids prognosis for weaning from MV was favorable in case of lower airway protection with cuffed tracheostomy tube and maintaining cuff pressure of at least $15-20 \mathrm{~mm} \mathrm{Hg}$.

Thus, comparison dynamics of consciousness level according to Glasgow Coma Scale and FOUR scale, the hypothesis that FOUR scale might more detailed evaluated mechanically ventilated patients was confirmed. Similarly, the Richmond agitation-sedation scale tends to have a higher diagnostic value compared to Ramsay sedation scale, as it allows us to assess not only the level of sedation, but also the agitation that occurs in patients on MV. 
Table 3. Presence of cough and swallowing reflexes

\begin{tabular}{||c|c|c|c|c||}
\hline \multicolumn{1}{|c|}{ Indicator } & Study stage & I group $(\mathrm{n}=81)$ & II group (n=71) & $\mathrm{P}^{\mathrm{a}}$ \\
\hline \multirow{3}{*}{$\begin{array}{l}\text { Presence of cough and } \\
\text { swallowing reflexes, } \mathrm{n}(\%)\end{array}$} & $\mathrm{d}_{1}$ & $61(75.3 \%)$ & $57(80 \%)$ & 0.28 \\
\cline { 2 - 5 } & $\mathrm{d}_{3}$ & $64(79 \%)$ & $61(85.9 \%)$ & 0.12 \\
\cline { 2 - 5 } & $\mathrm{d}_{5}$ & $67(82.7 \%)$ & $62(87.3 \%)$ & 0.23 \\
\cline { 2 - 5 } & $\mathrm{d}_{7}$ & $68(83.9 \%)$ & $63(88.7 \%)$ & 0.41 \\
\cline { 2 - 5 } & $\mathrm{d}_{9}$ & $68(83.9 \%)$ & $63(88.7 \%)$ & 0.41 \\
\cline { 2 - 5 } & $\mathrm{d}_{14}$ & $68(83.9 \%)$ & $63(88.7 \%)$ & 0.41 \\
\hline
\end{tabular}

Data are expressed as number (\%); $\mathrm{a}-\mathrm{x}^{2}$ test to compare two groups.

Frequency of elective tracheostomy before the first attempt to wean patient from MV in 1st age subgroup was higher in group II (11\%) in comparison with $0 \%$ in group I $(\mathrm{p}=0.001)$. Thus, a comprehensive approach to assessing central nervous system function with taking into account markers of submucosal edema of trachea which lead to postintubation stridor, the frequency of reintubations was reduced to $5.3 \%$ in group II compared with $22.7 \%$ in group I $(p=0.02)$. The frequency of elective tracheostomy in 2nd age subgroup was $18 \%$ in group II, compared with $5 \%$ in group I $(p=0.05)$, and the frequency of reintubation was reduced to $5.9 \%$ in group II compared with $20 \%$ in group I $(p=0.04)$. All listed above might be explained by the inclusion in criteria for safe and effective weaning from MV signs of bulbar disorders, which were detected in group II before weaning due to proposed by us patient assessment strategy. In addition, it should not be interpreted as a complication of treatment due to the fact that this strategy helps

\section{LITERATURE}

1. Dres M. Respective contribution of intensive care unit-acquired limb muscle and severe diaphragm weakness on weaning outcome and mortality: a post hoc analysis of two cohorts / M. Dres, B. Jung, N. Molinari [et al.] // Crit. Care. - 2019. - Vol. 23. - P. 370. - Access mode : https://doi.org/10.1186/s13054-019-2650-z

2. Saiphoklang N. Incidence and outcome of weaning from mechanical ventilation in medical wards at Thammasat University Hospital / N. Saiphoklang, J. Auttajaroon // PLoS One. - 2018. Vol. 13 (10). - P. e0205106. Published 2018 Oct 4. doi:10.1371/ journal.pone.0205106

3. Mechanical ventilation-induced diaphragm atrophy strongly impacts clinical outcomes / E. C. Goligher, M. Dres, E. Fan [et al.] // Am. J. Respir. Crit. Care Med. - 2018. - Vol. 197. P. 204-213.

4. Goonasekera C. D. A. Oxygen delivery and oxygen consumption in pediatric fluid refractory septic shock during the first $42 \mathrm{~h}$ of therapy and their relationship to 28-day outcome / C. D. A. Goonasekera, J. A. Carcillo, A. Deep // Front Pediatr. - 2018. - Vol. 6. - P. 314. DOI:10.3389/fped.2018.00314. us avoid possible reintubation of these patients and reduces the risk of many ventilator-associated complications.

There were no significant differences in the frequency of reintubations among patients in 3rd age subgroup (14.2 \% in group I vs $11.1 \%$ in group II, $\mathrm{p}$ $=0.31$ ); in 4th age subgroup ( $13 \%$ vs $17 \%, \mathrm{p}=0.19$ ); 5th age subgroup ( $6 \%$ vs $7 \%, p=0.72)$.

Conclusion. It was found that successful weaning from MV depends on absence of subglottic edema markers and on results of central nervous system function assessing. Our comprehensive approach, in addition to diaphragm-protective strategy of MV, reduces frequency of reintubations in 1 month -1 year and 1 year -3 years old mechanically ventilated children.

Prospects of further studies might be plan to increase number of included in study patients and comparison all indicators in relevant age subgroups.

Conflict of interest: none.

5. Tsegaye B. Serum transthyretin level as a plausible marker for diagnosis of child acute malnutrition / B. Tsegaye, A. Mekasha, S. Genet // Biochemistry Research International. 2017. - 6 p. Article ID 9196538. - Access mode : https://doi. org/10.1155/2017/9196538.

6. Mihatsch W. ESPGHAN/ESPEN/ESPR/CSPEN guidelines on pediatric parenteral nutrition: Calcium, phosphorus and magnesium / W. Mihatsch // Clinical Nutrition. - 2018. - Access mode : https://doi.org/10.1016/j.clnu.2018.06.950

7. Verhulst S. Influence of body mass index and Prealbumin levels on lung function in patients with spinal muscular atrophy: A pilot study / S. Verhulst, J. Haan, M. Toussaint // J. Clin. Neuromuscul. Dis. - 2019. - Vol. 20 (3). - P. 137-138. DOI: 10.1097/ CND.0000000000000225.

8. A Phase II randomized controlled trial for lung and diaphragm protective ventilation (Real-time Effort Driven VENTilator management) / G. Robinder Khemani, J. C. Hotz, M. J. Klein [et al.] // Contemporary Clinical Trials. - 2020. - Vol. 88. - P. 105893. Access mode : https://doi.org/10.1016/j.cct.2019.105893. 


\section{З ДОСВІДУ РОБОТИ}

\section{REFERENCES}

1. Dres, M., Jung, B., Molinari, N., Manna, F., Dubé, B., \& Chanques, G. et al. (2019). Respective contribution of intensive care unit-acquired limb muscle and severe diaphragm weakness on weaning outcome and mortality: a post hoc analysis of two cohorts. Critical Care, 23 (1). DOI: 10.1186/s13054-019-2650-z. 2. Saiphoklang, N., \& Auttajaroon, J. (2018). Incidence and outcome of weaning from mechanical ventilation in medical wards at Thammasat University Hospital. PLoS One, 13 (10), e0205106. Published 2018 Oct 4. DOI:10.1371/journal.pone.0205106.

3. Goligher, E., Dres, M., Fan, E., Rubenfeld, G., Scales, D., \& Herridge, M. et al. (2018). Mechanical ventilation-induced diaphragm atrophy strongly impacts clinical outcomes. American Journal of Respiratory and Critical Care Medicine, 197 (2), 204213. DOI: 10.1164/rccm.201703-0536oc.

4. Goonasekera, C., Carcillo, J., \& Deep, A. (2018). Oxygen delivery and oxygen consumption in pediatric fluid refractory septic shock during the first $42 \mathrm{~h}$ of therapy and their relationship to 28-day outcome. Frontiers in Pediatrics, 6. DOI: 10.3389/fped.2018.00314.
5. Tsegaye, B., Mekasha, A., \& Genet, S. (2017). Serum Transthyretin level as a plausible marker for diagnosis of child acute malnutrition. Biochemistry Research International, 2017, 1-6. DOI: $10.1155 / 2017 / 9196538$.

6. Mihatsch, W., Fewtrell, M., Goulet, O., Molgaard, C., Picaud, J., \& Senterre, T. et al. (2018). ESPGHAN/ESPEN/ESPR/CSPEN guidelines on pediatric parenteral nutrition: Calcium, phosphorus and magnesium. Clinical Nutrition, 37 (6), 2360-2365. DOI: 10.1016/j.clnu.2018.06.950.

7. Verhulst, S., Haan, J., \& Toussaint, M. (2020). Influence of body mass index and Prealbumin levels on lung function in patients with spinal muscular atrophy. J. Clin. Neuromuscul. Dis., 20 (3), 137-138. DOI: 10.1097/CND.0000000000000225.

8. Khemani, R., Hotz, J., Klein, M., Kwok, J., Park, C., \& Lane, C. et al. (2020). A phase II randomized controlled trial for lung and diaphragm protective ventilation (Real-time Effort Driven VENTilator management). Contemporary Clinical Trials, 88, 105893. DOI: 10.1016/j.cct.2019.105893.

Отримано 07.05.2020

Електронна адреса для листування: filyk_olha@meduniv.lviv.ua

о. В. ФІлик

Львівський національний медичний університет імені Данила Галицького

\section{НЕВДАЛЕ ВІДЛУЧЕННЯ ВІД ШТУЧНОӤ ВЕНТИЛЯЩЇ .ЛЕГЕНЬ У ДТТЕЙ ТА ІШЛЯХИ ЙОГО УНИКНЕННЯ}

Мета роботи: визначити причини невдалого відлучення від ШВЛ залежно від маркерів підзв'язкового набряку трахеї, рівня седації та седації-ажитації, змін неврологічного статусу та бульбарних порушень у дітей з різними формами дихальної недостатності.

Матеріали і методи. Проведено проспективне когортне одноцентрове дослідження у відділенні анестезіології з ліжками інтенсивної терапії КНП Львівської обласної дитячої клінічної лікарні “ОХМАТДИТ”. До дослідження було включено 89 пацієнтів (вік 1 міс. - 18 років) з гострою дихальною недостатністю, що потребували ШВЛ понад 3 доби. Їх було розділено випадковим чином на дві групи. У І групі застосовували легенево-протективну стратегію ШВЛ, оцінювали функцію центральної нервової системи та відсоток витоку дихальної суміші попри інтубаційну трубку; в II групі - легенево-протективну та діафрагм-протективну стратегії ШВЛ, оцінювали функцію центральної нервової системи та враховували отримані результати при відлученні від ШВЛ, оцінювали та враховували при відлученні від ШВЛ відсоток витоку дихальної суміші попри ендотрахеальну трубку. Первинною кінцевою точкою оцінювання була частота реінтубацій, вторинними точками оцінювання була частота ускладнень (трахеостомії). Пацієнтів було розділено на вікові підгрупи: 1 підгрупа - діти віком 1 міс. - 1 рік; 2 підгрупа - діти 1-3 роки; 3 підгрупа - діти 3-6 років; 4 підгрупа - діти 6 - 13 років; 5 підгрупа - діти 13-18 років. До аналізу даних включено 82 пацієнти. Результати досліджень та їх обговорення. Частота реінтубацій в пацієнтів 1-ї вікової підгрупи була знижена в II групі до $5,3$ \% порівняно з 22,7 \% в I групі ( $=0,02)$, що супроводжувалося вищою частотою планового накладання трахеостоми (до першої спроби відлучення від ШВЛ) серед пацієнтів II групи порівняно з І групою (11 \% порівняно 30 \%, p=0,001). Частота реінтубацій в 2-й віковій підгрупі була знижена до 5,9% в II групі порівняно з 20 \% в I групі (p=0,04), а накладання трахеостоми потребували $18 \%$, порівняно з 5 \% в ІІ та І групі відповідно (p=0,05).

Не виявлено достовірних відмінностей частоти реінтубацій серед пацієнтів: 3-ї вікової підгрупи (14,2% в I групі порівняно 3 11,1 \% в II групі, p=0,31); пацієнтів 4-ї вікової підгрупи (13\% порівняно з 17 \%, p=0,19); 5-ї вікової підгрупи (6 \% порівняно з $7 \%, \mathrm{p}=0,72)$.

Ключові слова: штучна вентиляція легень; діти. 
О. В. ФИЛЫк

Львовский национальный медицинский университет имени Данила Галицкого

\title{
НЕУДАЧНОЕ ОТ.УУЧЕНИЕ ОТ ИСКУССТВЕННОЙ ВЕНТИЛЯЦИИ ЛЕГКИХ У ДЕТЕЙ И ПУТИ ЕГО ПРЕДОТВРАШЕНИЯ
}

\begin{abstract}
Цель работы: установить причины неудачного отлучения от ИВЛ в зависимости от маркеров подсвязочного отека трахеи, уровня седации и седации-ажитации, изменений неврологического статуса и бульбарных нарушений у детей с различными формами дыхательной недостаточности.

Материалы и методы. Проведено проспективное когортное одноцентровое исследование в отделении анестезиологии с койками интенсивной терапии КНП Львовской областной детской клинической больницы “ОХМАТДЕТ”. В исследование включено 89 пациентов в возрасте 1 мес. - 18 лет с острой дыхательной недостаточностью, требующих ИВЛ более 3 суток. Они были случайным образом разделены на 2 группы. В І группе применяли легочно-протективную стратегию ИВЛ, оценивали функцию центральной нервной системы и процент утечки дыхательной смеси возле эндотрахеальной трубки; во II группе - легочнопротективную и диафрагм-протективную стратегии ИВЛ и учитывали результаты оценки функции центральной нервной системы и утечки дыхательной смеси возле эндотрахеальной трубки при проведении отлучения от ИВЛ. Первичной конечной точкой оценки была частота реинтубаций, вторичными точками оценки была частота осложнений (трахеостомии). Пациенты были разделены на возрастные подгруппы: 1 подгруппа - дети 1 мес. - 1 год; 2 подгруппа - дети 1-3 года; 3 подгруппа - дети 3-6 лет; 4 подгруппа - дети 6 - 13 лет; 5 подгруппа - дети 13-18 лет. В анализ данных включено 82 пациента.

Результаты исследований и их обсуждение. Частота реинтубаций у пациентов 1-й возрастной подгруппы была снижена во II группе до 5,3 \% по сравнению с 22,7 \% в I группе (р = 0,02), что сопровождалось высокой частотой планового наложения трахеостомы (до первой попытки отлучения от ИВЛ ) среди пациентов II группы по сравнению с I группой (11 \% по сравнению с 0 \%, p = 0,001). Частота реинтубаций во 2-й возрастной подгруппе была снижена до 5,9 \% во II исследуемой группе по сравнению с 20 \% в I исследуемой группе (p = 0,04), а в трахеостомии нуждались 18 \% по сравнению с 5 \% соответственно (р = 0,05). Не выявлено достоверных различий частоты реинтубаций среди пациентов 3-й возрастной подгруппы (14,2 \% в первой группе по сравнению с 11,1 \% во II группе, p = 0,31); 4-й возрастной подгруппы (13 \% по сравнению с 17 \%, p = 0,19); 5-й возрастной подгруппы (6 \% по сравнению с 7 \%, p = 0,72).
\end{abstract}

Ключевые слова: искусственная вентиляция легких; дети. 